\title{
A polymorphism of a platelet glycoprotein receptor as an inherited risk factor for coronary thrombosis.
}

\author{
Ethan J. Weiss \\ Johns Hopkins University School of Medicine \\ Paul F. Bray \\ Johns Hopkins University School of Medicine \\ Matthew Tayback \\ Johns Hopkins University School of Hygiene and Public Health \\ Steven P. Schulman \\ Johns Hopkins University School of Medicine \\ Fblpowałis_. aKifkaderitional works at: https://jdc.jefferson.edu/cardeza_foundation \\ Inhns Hopkins University School of Medicine \\ Part of the Hematology Commons

\section{Let us know how access to this document benefits you See next page for additional authors}

\section{Recommended Citation}

Weiss, Ethan J.; Bray, Paul F.; Tayback, Matthew; Schulman, Steven P.; Kickler, Thomas S.; Becker, Lewis C.; Weiss, James L.; Gerstenblith, Gary; and Goldschmidt-Clermont, Pascal J., "A polymorphism of a platelet glycoprotein receptor as an inherited risk factor for coronary thrombosis." (1996). Cardeza Foundation for Hematologic Research. Paper 19.

https://jdc.jefferson.edu/cardeza_foundation/19

This Article is brought to you for free and open access by the Jefferson Digital Commons. The Jefferson Digital Commons is a service of Thomas Jefferson University's Center for Teaching and Learning (CTL). The Commons is a showcase for Jefferson books and journals, peer-reviewed scholarly publications, unique historical collections from the University archives, and teaching tools. The Jefferson Digital Commons allows researchers and interested readers anywhere in the world to learn about and keep up to date with Jefferson scholarship. This article has been accepted for inclusion in Cardeza Foundation for Hematologic Research by an authorized administrator of the Jefferson Digital Commons. For more information, please contact: JeffersonDigitalCommons@jefferson.edu. 


\section{Authors}

Ethan J. Weiss, Paul F. Bray, Matthew Tayback, Steven P. Schulman, Thomas S. Kickler, Lewis C. Becker, James L. Weiss, Gary Gerstenblith, and Pascal J. Goldschmidt-Clermont 


\title{
A POLYMORPHISM OF A PLATELET GLYCOPROTEIN RECEPTOR AS AN INHERITED RISK FACTOR FOR CORONARY THROMBOSIS
}

\author{
Ethan J. Weiss, B.A., Paul F. Bray, M.D., Matthew Taybagk, Sc.D., Steven P. Schulman, M.D., \\ Thomas S. Kickler, M.D., Lewis C. Becker, M.D., James L. Weiss, M.D., Gary Gerstenblith, M.D., \\ and Pascal J. Goldschmidt-Glermont, M.D.
}

\begin{abstract}
Background. Platelet glycoprotein Ilb/llla is a membrane receptor for fibrinogen and von Willebrand factor, and it has an important role in platelet aggregation. It is known to be involved in the pathogenesis of acute coronary syndromes. Previously, we found a high frequency of a particular polymorphism, $P P^{A 2}$, of the gene encoding glycoprotein Illa in kindreds with a high prevalence of premature myocardial infarction.

Methods. To investigate the relation between the $P P^{A 2}$ polymorphism and acute coronary syndromes, we conducted a case-control study of 71 case patients with myocardial infarction or unstable angina and 68 inpatient controls without known heart disease. The groups were matched for age, race, and sex. We used two methods to determine the $P I^{A}$ genotype: reverse dot blot hybridization and allele-specific restriction digestion.
\end{abstract}

Results. The prevalence of $P I^{A 2}$ was 2.1 times higher

$\mathrm{S}^{\mathrm{T}}$ TUDIES indicate that myocardial infarction and unstable angina result from the formation of a platelet aggregate at the site of a ruptured coronary atherosclerotic plaque. ${ }^{1-7}$ The formation of such aggregates requires the binding of fibrinogen and von Willebrand factor to the receptor, glycoprotein IIb/IIIa, on the platelet surface. ${ }^{6,8,9}$ Large trials have demonstrated a marked benefit of various inhibitors of platelet function in both preventing and reducing the mortality and morbidity associated with unstable coronary syndromes. ${ }^{10-26}$ Additional studies have linked ex vivo platelet reactivity to outcome in patients after myocardial infarction. ${ }^{27}$ In sum, there is strong evidence that platelets, and glycoprotein IIb/IIIa in particular, have an important role in the pathogenesis of acute coronary syndromes.

Platelet-membrane glycoproteins are highly polymorphic and can be recognized as alloantigens or autoantigens..$^{28}$ The alloimmune thrombocytopenias are due to the incompatibility of epitopes on the various platelet-surface glycoproteins. ${ }^{29}$ The alloantigen referred to as $\mathrm{Pl}^{\mathrm{A}}$ or $\mathrm{Zw}$ is the one most frequently implicated in syndromes of immune-mediated platelet destruction. $^{30,31}$ Kunicki and Aster demonstrated that

From the Department of Medicine, Divisions of Cardiology (E.J.W., S.P.S., L.C.B., J.L.W., G.G., P.J.G.-C.) and Hematology (E.J.W., P.F.B., T.S.K.), the Department of Pathology (P.F.B., T.S.K.), and the Department of Cell Biology and Anatomy (P.J.G.-C.), Johns Hopkins University School of Medicine; and Johns Hopkins University School of Hygiene and Public Health (M.T.) - both in Baltimore. Address reprint requests to Dr. Goldschmidt-Clermont at Bernard Laboratory, Ross 1023, Johns Hopkins Medical School, 720 Rutland Ave., Baltimore, MD 21205.

Supported by grants from the National Institutes of Health (HL49762 and NR02241), a grant from the Rebecca and Bernard Bernard Foundation, the Ciccarone Center for the Prevention of Heart Disease, and the Rogers-Wilbur Foundation. Dr. Goldschmidt-Clermont is an Established Investigator of the American Heart Association. among the case patients than among the controls (39.4 percent vs. 19.1 percent, $\mathrm{P}=0.01)$. In a subgroup of patients whose disease began before the age of 60 years, the prevalence of $P^{A 2}$ was 50 percent, a value that was 3.6 times that among control subjects under 60 years of age (13.9 percent, $P=0.002$ ). Among subjects with the $P^{A 2}$ polymorphism, the odds ratio for having a coronary event was 2.8 (95 percent confidence interval, 1.2 to 6.4). In the patients less than 60 years of age at the onset of disease, the odds ratio was 6.2 (95 percent confidence interval, 1.8 to 22.4 ).

Conclusions. We observed a strong association between the $P I^{A 2}$ polymorphism of the glycoprotein Illa gene and acute coronary thrombosis, and this association was strongest in patients who had had coronary events before the age of 60 years. (N Engl J Med 1996;334:1090-4.)

(01996, Massachusetts Medical Society.

anti- $\mathrm{Pl}^{\mathrm{Al}}$ antiserum from $\mathrm{Pl}^{\mathrm{Al}}$-negative persons reacted with platelet glycoprotein IIIa. ${ }^{32}$ Subsequently, Newman et al. identified the molecular basis of this polymorphism: persons positive for $\mathrm{Pl}^{\mathrm{Al}}$ have a leucine at position 33 of mature glycoprotein IIIa; persons positive for $\mathrm{Pl}^{\mathrm{A} 2}$ have a proline at this position, which is the result of the substitution of cytosine for thymidine at position 1565 in exon 2 of the glycoprotein IIIa gene. ${ }^{33}$ We recently determined the allelic frequencies of $P l^{A I}$ and $P l^{A 2}$ in several racial and ethnic groups in the metropolitan Baltimore area. ${ }^{34}$

Previously, we found an unexpectedly high frequency of family members homozygous for $P l^{A 2}$ in kindreds with a high prevalence of acute coronary events at a relatively young age (under 60 years). ${ }^{35}$ This observation led us to postulate that the presence of at least one $P l^{A 2}$ allele may be related to the development of symptomatic unstable coronary heart disease. We conducted a case-control study to examine whether there was an association between the $P l^{A 2}$ allele and unstable coronary syndromes, especially in persons less than 60 years of age.

\section{Methods}

\section{Selection of Case Patients and Control Subjects}

Studies on case patients and control subjects were approved by the Joint Committee for Clinical Investigation of Johns Hopkins University and Hospital. Genotypic analyses were performed on 71 consecutive case patients admitted to the Coronary Care Unit of Johns Hopkins Hospital with an established diagnosis of myocardial infarction or unstable angina as defined by World Health Organization criteria. Similar genotypic analyses were performed on control subjects matched with the case patients for age, race, and sex, but who had no documented history of either stable or unstable angina or myocardial infarction. The control subjects were selected by reviewing patient charts from a population of patients admitted to the general medical 
and intensive care services of the hospital. We selected 68 consecutive subjects who fulfilled these criteria.

\section{Demographic Characteristics}

Demographic data were obtained on each subject from the official medical record at the time of enrollment and included the current age (for control subjects), the age at the time of a first event (for case patients), sex, smoking history, blood pressure, total serum cholesterol level, diabetes status, and history of coronary events. Because the prevalence of the $P l^{A 2}$ allele is known to be lower among blacks than among whites, we limited the study to the white population. ${ }^{34,36}$

\section{Determination of $P I^{A}$ Genotypes}

Genomic DNA was isolated from $200 \mu \mathrm{l}$ of whole blood as previously described or with the QIAamp blood kit (Qiagen, Chatsworth, Calif.). ${ }^{37}$ To detect the substitution of cytosine for thymidine responsible for the $P l^{A 2}$ polymorphism at position 1565 in exon 2 of the glycoprotein IIIa gene, we used both reverse dot blot hybridization and allele-specific restriction digestion (exon numbering and nucleotide sequence are from Zimrin et al. ${ }^{38}$ ). Exon 2 was amplified from genomic DNA from case patients or controls in a polymerase chain reaction (PCR) with primers flanking the exon, as previously described ${ }^{39}$ For the reverse dot blot hybridization reaction, oligonucleotides specific for either the $P l^{A 1}$ or $P l^{A 2}$ allele were covalently attached to filters and hybridized with biotinylated PCR products of glycoprotein IIIa exon 2 , and reactivity was assessed by an enhanced chemiluminescence technique, as described previously. ${ }^{34,37}$ These allele-specific hybridization data were confirmed with restriction-enzyme digestion with $M s p \mathrm{I}$ and $\mathrm{Nci}$ ( New England Biolabs, Beverly, Mass.), which are able to distinguish the $P l^{A 1}$ allele from the $P l^{A 2}$ allele because new restriction sites are generated as the result of the $P l^{A 2}$ polymorphism. Exon 2 PCR products were digested separately with both enzymes, and the resulting fragments were analyzed on a 3 percent agarose gel. The results of both techniques were confirmed by at least two independent investigators who were unaware of the origin of the DNA.

\section{Statistical Analysis}

The size of the sample was established after pilot studies indicated that the prevalence of $P l^{42}$ among the case patients would be approximately 40 percent and the expected prevalence in control subjects would not exceed 20 percent. With the expectation that a difference of this magnitude would strongly support the concept that $P l^{A 2}$ is a significant genetic risk factor, and with a one-sided alpha error of 0.05 , the size of the sample was set at 71 to limit the beta error to 0.1. Student's t-test was used to compare established risk factors for coronary heart disease in the case patients and the control subjects, with a twotailed test used for the continuous variables. A P value of 0.05 or less was considered to indicate statistical significance. Discrete data (including data on the $P l^{A}$ alleles) were analyzed by the chi-square test. The strength of the association of the $P l^{A 2}$ genetic factor with the occurrence of acute coronary events was estimated by calculation of the odds ratios with EpiInfo software (version 6, Centers for Disease Control and Prevention, Atlanta) and the Cornfield method for the calculation of 95 percent confidence intervals. The relative strength of association of other risk factors was measured in a similar manner. The significance of the difference in the odds ratios was not tested, since the sample size was not designed for such analyses. The relation of the $P l^{A}$ allele to each of the remaining predictor variables was examined by bivariate chi-square analysis. Finally, the association of the $P l^{42}$ allele with coronary events, standardized for the other risk factors, was determined by the multiple logistic-regression method with the Stata statistical package (version 4.0, Stata, College Station, Tex.).

\section{ReSUlts}

\section{Characteristics of the Study Population}

Table 1 shows the prevalence of selected risk factors for coronary heart disease among the case patients and controls. The two groups were matched according to age, race, and sex, and there were therefore no significant differences in these variables. Owing to the sample size, the only risk factor that differed significantly between the groups was smoking status $(\mathrm{P}=0.05)$.

\section{Prevalence of $P^{A 2}$}

Genotyping results for 3 of the 71 case patients are shown in Figure 1, demonstrating the three possible $P l^{A}$ allelic combinations. Table 2 summarizes the genotyping data for all case patients and controls. The prevalence of $P l^{A 2}$ among the case subjects was 39.4 percent (percentage of subjects who were either heterozygous $\left[P l^{A 1} / P l^{A 2}\right]$ or homozygous $\left.\left[P l^{A 2} / P l^{A 2}\right]\right)$, a value that was significantly higher than the prevalence among the 68 controls (19.1 percent, $\mathrm{P}=0.01$ ). The association between $P l^{A 2}$ and coronary events was even stronger in patients who were less than 60 years of age when they had their first coronary event. Of the 42 such patients, 50 percent carried at least one $P l^{A 2}$ allele, as compared with 13.9 percent of the 36 controls who were less than 60 years of age $(\mathrm{P}=0.002)$.

\section{Comparison of Major Risk Factors for Coronary Heart Disease}

Among the major risk factors for coronary heart disease examined in this study, the risk factor associated with the highest estimated odds ratio was carriage of the $P l^{A 2}$ allele (odds ratio, 2.8; 95 percent confidence interval, 1.2 to 6.4 ), followed in order by smoking (odds ratio, 2.2; 95 percent confidence interval, 1.0 to 4.8), hypertension (systolic blood pressure, $\geqslant 140 \mathrm{~mm} \mathrm{Hg}$ ) (odds ratio, 1.9; 95 percent confidence interval, 0.9 to 3.9), and hypercholesterolemia (total serum cholesterol level, $\geqslant 200 \mathrm{mg}$ per deciliter [5.2 mmol per liter]) (odds ratio, 1.3; 95 percent confidence interval, 0.5 to 3.0 ) (Table 3 ). The prevalence of diabetes mellitus was sim-

Table 1. Prevalence of Selected Risk Factors for Coronary Heart Disease among Case Patients and Controls.

\begin{tabular}{|c|c|c|c|}
\hline RISK FACTOR & $\begin{array}{c}\text { CASE } \\
\text { PATIENTS } \\
(\mathrm{N}=71)\end{array}$ & $\begin{array}{l}\text { CONTROLS } \\
(\mathrm{N}=68)\end{array}$ & $\begin{array}{c}P \\
\text { VALUE* }\end{array}$ \\
\hline Age $(y r) \dagger$ & $56.3 \pm 12.8$ & $58.3 \pm 14.3$ & 0.39 \\
\hline Male sex $(\%)$ & 70 & 69 & 0.99 \\
\hline Hypertension $(\%) \ddagger$ & 52 & 37 & 0.10 \\
\hline Current or former smoker $(\%)$ & 72 & 55 & 0.05 \\
\hline Hypercholesterolemia $(\%) \S$ & 26 & 22 & 0.69 \\
\hline $\begin{array}{l}\text { Type I or II diabetes mellitus } \\
(\%)\end{array}$ & 18 & 22 & 0.73 \\
\hline
\end{tabular}

*Student's t-test (for continuous variables) and the chi-square test (for discrete variables) were used to compare the values for case patients and controls.

$\nmid$ Plus-minus values are means \pm SD; for the case patients, the value refers to the age at onset of myocardial infarction or unstable angina, not the current age.

$\ddagger$ Hypertension was defined as a systolic blood pressure $\geqslant 140 \mathrm{~mm} \mathrm{Hg}$ at the time of admission to the hospital.

$\S$ Hypercholesterolemia was defined as a total serum cholesterol level $\geqslant 200 \mathrm{mg}$ per deciliter $(5.2 \mathrm{mmol}$ per liter) at the time of admission to the hospital. 


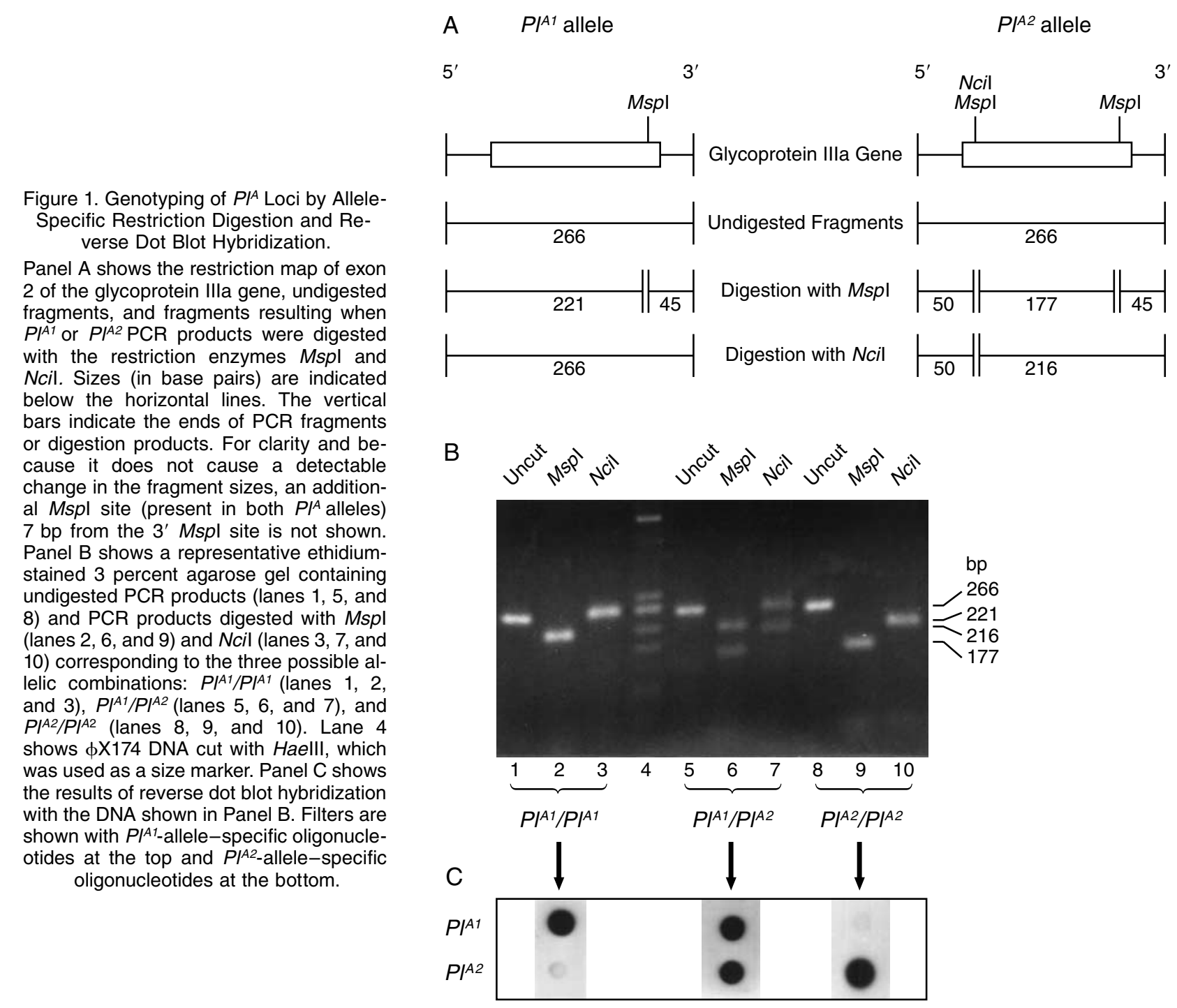

ilarly high among case patients and control subjects. As anticipated, the odds ratios for each of the risk factors, including $P l^{A 2}$, were higher in the subgroup of case patients less than 60 years of age than in controls less than 60 years of age. In this subgroup, the risk factor associated with the highest estimated odds ratio was again the $\mathrm{Pl}^{A 2}$ allele (odds ratio, 6.2; 95 percent confidence interval, 1.8 to 22.4 ), followed in order by smoking (odds ratio, 3.8; 95 percent confidence interval, 1.2 to 12.0), hypercholesterolemia (odds ratio, 3.7; 95 percent confidence interval, 0.8 to 18.7 ), and hypertension (odds ratio, 2.1; 95 percent confidence interval, 0.7 to 5.9) (Table 3).

A multiple logistic-regression model that adjusted for the presence of smoking, hypertension, hypercholesterolemia, and an age greater than 60 years provided an odds ratio of 3.3 (95 percent confidence interval, 1.4 to 7.7) for the relation between acute coronary events and the $P l^{A 2}$ allele. This was consistent with the finding that the bivariate association of the allele with smoking, hy- pertension, hypercholesterolemia, and an age greater than 60 years was uniformly not statistically significant (data not shown).

\section{Discussion}

Our data demonstrate an association between the $P l^{A 2}$ polymorphism of glycoprotein IIIa and the occurrence of acute coronary thrombosis. We found a significantly higher prevalence of subjects with at least one $P l^{A 2}$ allele among those with either myocardial infarction or unstable angina than among a control group matched for sex, age, and race. If this polymorphism represents an inherited risk factor for myocardial infarction or unstable angina, one would predict an even higher prevalence of this risk factor among persons in whom these disorders occur at a younger age (before the age of 60 years), and this is what we found.

Data from northern and central Europe estimate the phenotypic frequency and genotypic frequency of $\mathrm{Pl}^{A 2}$ to be 26.5 percent and 15 percent, respectively. ${ }^{40}$ These 
Table 2. Genotypes of the Case Patients and Controls According to Age.*

\begin{tabular}{|c|c|c|c|}
\hline GENOTYPE & $\begin{array}{c}\text { CASE } \\
\text { PatIENTS }\end{array}$ & CONTROLS & $\begin{array}{c}\text { P } \\
\text { VALUE }\end{array}$ \\
\hline & \multicolumn{3}{|c|}{ no. $(\%)$} \\
\hline \multicolumn{4}{|l|}{ All ages } \\
\hline$P l^{A l} / P l^{A l}$ & $43(60.6)$ & $55(80.9)$ & \\
\hline$P l^{A l} / P l^{A 2}+P l^{A 2} / P l^{A 2}$ & $23+5(39.4)$ & $12+1(19.1)$ & 0.01 \\
\hline Total & $71(100)$ & $68(100)$ & \\
\hline \multicolumn{4}{|l|}{ Age $<60 \mathrm{yr}$} \\
\hline$P l^{A l} / P l^{A l}$ & $21(50)$ & $31(86.1)$ & \\
\hline$P l^{A 1} / P l^{A 2}+P l^{A 2} / P l^{A 2}$ & $19+2(50)$ & $5+0(13.9)$ & 0.002 \\
\hline Total & $42(100)$ & $36(100)$ & \\
\hline
\end{tabular}

* Subjects with the $P l^{A l} / P l^{A I}$ genotype were classified as $P l^{A 2}$-negative, and subjects with the $P l^{A l} / P l^{A 2}$ or $P l^{A 2} / P l^{A 2}$ genotype were classified as $P l^{A 2}$-positive. For the case patients, age refers to the age at onset of myocardial infarction or unstable angina, not the current age.

$\dagger$ The chi-square test was used to compare the prevalence of $P l^{A 2}$ in case patients and controls.

estimates were derived from studying subjects whose genetic background may differ from that of our subjects. In our previous work, we determined that the prevalence of $P l^{A 2}$ among 100 white subjects from the Baltimore area was 20 percent (genotypic frequency, 11 percent). ${ }^{34}$ As compared with the subjects in the European studies, the control subjects in the current study had a slightly lower prevalence of $P l^{A 2}$ (19.1 percent vs. 26.5 percent), but one that was virtually identical to the prevalence in our previous study in Baltimore. Between our two studies we have performed genotyping on 336 chromosomes from white control subjects, and the results provide very strong evidence that the prevalence of $\mathrm{Pl}^{A 2}$ among these subjects in the metropolitan Baltimore area is approximately 20 percent. For this reason, we believe the data on control subjects in the current study accurately reflect the population genetics in our geographic area and that this group is a valid one to use for comparison with our case patients.

Finally, although variation in the genetic background is the most likely explanation for differences in the prevalence of the $P l^{A 2}$ phenotype between the United States and Europe, the earlier studies of European pop- ulations used immunophenotyping, which is less specific than genotyping.

To assess the association between $P l^{A 2}$ and acute coronary events, we compared the risk of having a coronary event associated with the $P l^{A 2}$ polymorphism with that associated with four major cardiac risk factors. Among the major risk factors tested, the one associated with the largest odds ratio of having a coronary event, both for the entire group and for the subgroup of younger patients (age less than 60 years at first acute coronary event), was the $P l^{A 2}$ allele (Table 3 ). In addition, we conducted a multiple logistic-regression analysis adjusting for the presence of smoking, hypertension, hypercholesterolemia, and an age greater than 60 years, which demonstrated an independent association between $P l^{A 2}$ and acute coronary events. All the risk factors tested yielded odds ratios consistent with what one would expect for a major risk factor for coronary heart disease, except for diabetes. However, we believe that the low odds ratio associated with diabetes is a result of the selection of control subjects from a population of inpatients with a high prevalence of diabetes.

One theoretical explanation for the increased prevalence of $P l^{A 2}$ among the case patients could be a higher survival rate after myocardial infarction in this group than in $P l^{A 2}$-negative patients. However, if $P l^{A 2}$ did provide a survival advantage, the prevalence of $P l^{A 2}$ would be unlikely to be increased among the case patients in whom disease occurred before the age of 60 years. Instead, our hypothesis is that $P l^{A 2}$ is a risk factor for coronary heart disease events, particularly among younger persons. In fact, among the case patients, there was a significant difference of more than 7 years in the age at onset of disease between the $\mathrm{Pl}^{42}$-positive patients and the $P l^{A 2}$-negative patients ( 51.8 vs. 59.2 years, $\left.\mathrm{P}=0.02\right)$.

In addition to our findings related to the prognostic potential of $P l^{A 2}$, our results could directly affect the treatment of acute coronary events. For example, although aspirin has been the platelet inhibitor of choice for the treatment of unstable coronary syndromes, re-

Table 3. Odds Ratios for Selected Risk Factors, According to Age.*

\begin{tabular}{|c|c|c|c|c|c|c|c|}
\hline \multirow[t]{2}{*}{ FACTOR } & \multirow[t]{2}{*}{ Class } & \multicolumn{3}{|c|}{ All AgEs } & \multicolumn{3}{|c|}{ AGE $<60$ YR } \\
\hline & & $\begin{array}{c}\text { NO. OF } \\
\text { CASE PATIENTS }\end{array}$ & $\begin{array}{l}\text { NO. OF } \\
\text { CONTROLS }\end{array}$ & $\begin{array}{l}\text { ODDS RATIO } \\
(95 \% \mathrm{CI})\end{array}$ & $\begin{array}{c}\text { NO. OF } \\
\text { CASE PATIENTS }\end{array}$ & $\begin{array}{l}\text { NO. OF } \\
\text { CONTROLS }\end{array}$ & $\begin{array}{l}\text { ODDS RATIO } \\
(95 \% \mathrm{CI})\end{array}$ \\
\hline$P l^{A}$ genotype & $\begin{array}{l}P l^{A 2} \text {-positive } \dagger \\
P l^{A 2} \text {-negative }\end{array}$ & $\begin{array}{l}28 \\
43\end{array}$ & $\begin{array}{l}13 \\
55\end{array}$ & $2.8(1.2-6.4)$ & $\begin{array}{l}21 \\
21\end{array}$ & $\begin{array}{r}5 \\
31\end{array}$ & $6.2(1.8-22.4)$ \\
\hline Smoking status & $\begin{array}{c}\text { Current or former } \\
\text { Never }\end{array}$ & $\begin{array}{l}50 \\
19\end{array}$ & $\begin{array}{l}36 \\
30\end{array}$ & $2.2(1.0-4.8)$ & $\begin{array}{r}32 \\
8\end{array}$ & $\begin{array}{l}18 \\
17\end{array}$ & $3.8(1.2-12.0)$ \\
\hline $\begin{array}{l}\text { Systolic blood pressure on ad- } \\
\text { mission }\end{array}$ & $\begin{array}{l}\geqslant 140 \mathrm{~mm} \mathrm{Hg} \\
<140 \mathrm{~mm} \mathrm{Hg}\end{array}$ & $\begin{array}{l}36 \\
33\end{array}$ & $\begin{array}{l}25 \\
43\end{array}$ & $1.9(0.9-3.9)$ & $\begin{array}{l}19 \\
21\end{array}$ & $\begin{array}{l}11 \\
25\end{array}$ & $2.1(0.7-5.9)$ \\
\hline $\begin{array}{l}\text { Total serum cholesterol on ad- } \\
\text { mission }\end{array}$ & $\begin{array}{l}\geqslant 200 \mathrm{mg} / \mathrm{dl} \\
<200 \mathrm{mg} / \mathrm{dl}\end{array}$ & $\begin{array}{l}18 \\
50\end{array}$ & $\begin{array}{l}15 \\
53\end{array}$ & $1.3(0.5-3.0)$ & $\begin{array}{l}10 \\
30\end{array}$ & $\begin{array}{r}3 \\
33\end{array}$ & $3.7(0.8-18.7)$ \\
\hline Diabetes mellitus & $\begin{array}{l}\text { Type I or II } \\
\text { None }\end{array}$ & $\begin{array}{l}13 \\
58\end{array}$ & $\begin{array}{l}15 \\
53\end{array}$ & -† & $\begin{array}{r}8 \\
34\end{array}$ & $\begin{array}{r}8 \\
28\end{array}$ & $-\ddagger$ \\
\hline
\end{tabular}

*The total number of patients and controls for individual risk factors may not equal 71 and 68 , respectively, since data were missing for some subjects. For the case patients, age refers to the age at onset of myocardial infarction or unstable angina, not the current age. CI denotes confidence interval.

$\dagger$ Subjects with the $P l^{A 1} / P l^{A 2}$ or $P l^{A 2} / P l^{A 2}$ genotype were classified as $P l^{A 2}$-positive.

$\ddagger$ The odds ratio was not calculated because the control subjects were selected from a population of inpatients with a high prevalence of diabetes. 
cent studies indicate that treatment with specific inhibitors of glycoprotein IIb/IIIa leads to better outcomes than does aspirin therapy. ${ }^{23-26,41}$ It is conceivable that $P l^{A 2}$-positive patients would receive extra benefit from direct therapy with anti-glycoprotein IIb/IIIa, providing a rationale for decisions regarding the choice of antiplatelet therapy for patients with unstable coronary syndromes. ${ }^{41}$

We are indebted to the members of Kindred PT1 for their invaluable contribution to this study; to Hyun Kim, Emily E. Milliken, Ying Jin, William S. Shear, and Lindsay D. Coleman for excellent technical support; to Dr. Pamela Ouyang, Lydia Nelson, and members of the medical house staff and nursing staff of Johns Hopkins Hospital for assistance in the recruitment of patients and the procurement of blood samples; to Drs. Kenneth L. Baughman and Roger Blumenthal for providing medical records and scientific expertise; and to Dr. Paul M. Ridker for thoughtful discussions.

\section{REFERENCES}

1. Chandler AB, Chapman I, Erhardt LR, et al. Coronary thrombosis in myocardial infarction: report of a workshop on the role of coronary thrombosis in the pathogenesis of acute myocardial infarction. Am J Cardiol 1974;34: 823-33.

2. Lam JYT, Chesebro JH, Steele PM, Dewanjee MK, Badimon L, Fuster V. Deep arterial injury during experimental angioplasty: relation to a positive indium-111-labeled platelet scintigram, quantitative platelet deposition and mural thrombosis. J Am Coll Cardiol 1986;8:1380-6.

3. Fitzgerald DJ, Roy L, Catella F, FitzGerald GA. Platelet activation in unstable coronary artery disease. N Engl J Med 1986;315:983-9.

4. Davies MJ. A macro and micro view of coronary vascular insult in ischemic heart disease. Circulation 1990;82:Suppl:II-38-II-46.

5. Fuster V, Badimon L, Badimon JJ, Chesebro JH. The pathogenesis of coronary artery disease and the acute coronary syndromes. N Engl J Med 1992; 326:242-50.

6. Jang Y, Lincoff AM, Plow EF, Topol EJ. Cell adhesion molecules in coronary artery disease. J Am Coll Cardiol 1994;24:1591-601.

7. DeWood MA, Stifter WF, Simpson CS, et al. Coronary arteriographic findings soon after non-Q-wave myocardial infarction. N Engl J Med 1986;315: 417-23.

8. Plow EF, Ginsberg MH. Cellular adhesion: GPIIb-IIIa as a prototypic adhesion receptor. Prog Hemost Thromb 1989;9:117-56.

9. Coller BS. Platelets and thrombolytic therapy. N Engl J Med 1990;322:3342.

10. Lewis HD Jr, Davis JW, Archibald DG, et al. Protective effects of aspirin against acute myocardial infarction and death in men with unstable angina: results of a Veterans Administration Cooperative study. N Engl J Med 1983; 309:396-403.

11. Cairns JA, Gent M, Singer J, et al. Aspirin, sulfinpyrazone, or both in unstable angina: results of a Canadian Multicenter Trial. N Engl J Med 1985;313: $1369-75$.

12. ISIS-2 (Second International Study of Infarct Survival) Collaborative Group. Randomized trial of intravenous streptokinase, oral aspirin, both, or neither among 17187 cases of suspected acute myocardial infarction: ISIS2. Lancet 1988;2:349-60.

13. Ridker PM, Manson JE, Buring JE, Muller JE, Hennekens CH. Circadian variation of acute myocardial infarction and the effect of low-dose aspirin in a randomized trial of physicians. Circulation 1990;82:897-902.

14. Ridker PM, Manson JE, Gaziano JM, Buring JE, Hennekens CH. Low-dose aspirin therapy for chronic stable angina: a randomized, placebo-controlled clinical trial. Ann Intern Med 1991;114:835-9.

15. Ridker PM, Manson JE, Buring JE, Goldhaber SZ, Hennekens CH. Clinical characteristics of nonfatal myocardial infarction among individuals on prophylactic low-dose aspirin therapy. Circulation 1991;84:708-11.

16. Verheut FW, van der Laarse A, Funke-Kupper AJ, Sterkman LG, Galema TW, Roos JP. Effects of early intervention with low-dose aspirin $(100 \mathrm{mg})$ on infarct size, reinfarction and mortality in anterior wall acute myocardial infarction. Am J Cardiol 1990;66:267-70.
17. The RISC Group. Risk of myocardial infarction and death during treatment with low dose aspirin and intravenous heparin in men with unstable coronary artery disease. Lancet 1990;336:827-30.

18. Nyman I, Larsson H, Wallentin L. Prevention of serious cardiac events by low-dose aspirin in patients with silent myocardial ischemia: the Research Group on Instability in Coronary Artery Disease in Southeast Sweden. Lancet 1992;340:497-501.

19. Juul-Moller S, Edvardsson N, Jahnmatz B, Rosen A, Sorenson S, Omblus R. Double-blind trial of aspirin in primary prevention of myocardial infarction in patients with stable chronic angina pectoris: the Swedish Angina Pectoris Aspirin Trial (SAPAT) Group. Lancet 1992;340:1421-5.

20. Hoffman W, Förster W. Two year Cottbus reinfarction study with $30 \mathrm{mg}$ aspirin per day. Prostaglandins Leukot Essent Fatty Acids 1991;44:159-69.

21. The Persantine-Aspirin Reinfarction Study Research Group. Persantine and aspirin in coronary heart disease. Circulation 1980;62:449-61.

22. Klimt CR, Knatterud GL, Stamler J, Meier P. Persantine-Aspirin Reinfarction Study. II. Secondary coronary prevention with persantine and aspirin. J Am Coll Cardiol 1986;7:251-69.

23. Gold HK, Gimple LW, Yasuda T, et al. Pharmacodynamic study of F(ab' $)_{2}$ fragments of murine monoclonal antibody 7E3 directed against human platelet glycoprotein IIb/IIIa in patients with unstable angina pectoris. J Clin Invest 1990;86:651-9.

24. Coller BS. Blockade of platelet GPIIb/IIIa receptors as an antithrombotic strategy. Circulation 1995;92:2373-80.

25. Mickelson JK, Simpson PJ, Lucchesi BR. Antiplatelet monoclonal F(ab') antibody directed against the platelet GPIIb/IIIa receptor complex prevents coronary artery thrombosis in the canine heart. J Mol Cell Cardiol 1989; 21:393-405.

26. The EPIC Investigators. Use of a monoclonal antibody directed against the platelet glycoprotein IIb/IIIa receptor in high-risk coronary angioplasty. N Engl J Med 1994;330:956-61.

27. Trip MD, Cats VM, van Capelle FJL, Vreeken J. Platelet hyperreactivity and prognosis in survivors of myocardial infarction. N Engl J Med 1990; 322:1549-54

28. Newman PJ, McFarland JG, Aster RH. Alloimmune thrombocytopenias. In: Loscalzo J, Schafer AI, eds. Thrombosis and hemorrhage. Boston: Blackwell Scientific, 1994:529-43.

29. Kickler TS. Platelet immunology. In: Anderson KC, Ness PM, eds. Scientific basis of transfusion medicine: implications for clinical practice. Philadelphia: W.B. Saunders, 1994:304-15.

30. Shulman NR, Aster RH, Leitner A, Hiller MC. Immunoreactions involving platelets. V. Post-transfusion purpura due to a complement-fixing antibody against a genetically controlled platelet antigen: a proposed mechanism for thrombocytopenia and its relevance in "autoimmunity." J Clin Invest 1961; 40:1597-620.

31. van Loghem JJ Jr, Dorfmeijer H, van der Hart M, Schreuder F. Serological and genetical studies on a platelet antigen (Zw). Vox Sang 1959;4:161-9.

32. Kunicki TJ, Aster RH. Isolation and immunologic characterization of the human platelet alloantigen, $\mathrm{Pl}^{\mathrm{A} 1}$. Mol Immunol 1979;16:353-60.

33. Newman PJ, Derbes RS, Aster RH. The human platelet alloantigens, $\mathrm{Pl}^{\mathrm{Al}}$ and $\mathrm{Pl}^{\mathrm{A} 2}$, are associated with a leucine ${ }^{33} /$ proline $^{33}$ amino acid polymorphism in membrane glycoprotein IIIa, and are distinguishable by DNA typing. J Clin Invest 1989;83:1778-81

34. Kim HO, Jin Y, Kickler TS, Blakemore K, Kwon OH, Bray PF. Gene frequencies of the five major human platelet antigens in African American, white, and Korean populations. Transfusion 1995;35:863-7.

35. Weiss EJ, Goldschmidt-Clermont PJ, Grigoryev D, Jin Y, Kickler TS, Bray PF. A monoclonal antibody (SZ21) specific for platelet GPIIIa distinguishes $\mathrm{Pl}^{\mathrm{A} 1}$ from $\mathrm{Pl}^{\mathrm{A} 2}$. Tissue Antigens 1995;46:374-81.

36. Ramsey G, Salamon DJ. Frequency of $P^{A 1}$ in blacks. Transfusion 1986;26: 531-2.

37. Bray PF, Jin Y, Kickler T. Rapid genotyping of the five major platelet alloantigens by reverse dot-blot hybridization. Blood 1994;84:4361-7.

38. Zimrin AB, Gidwitz S, Lord S, et al. The genomic organization of platelet glycoprotein IIIa. J Biol Chem 1990;265:8590-5.

39. Jin Y, Dietz HC, Nurden A, Bray PF. Single-strand conformation polymorphism analysis is a rapid and effective method for the identification of mutations and polymorphisms in the gene for glycoprotein IIIa. Blood 1993; $82: 2281-8$.

40. von dem Borne AEG, Decary F. Nomenclature of platelet-specific antigens. Transfusion 1990;30:477.

41. Lefkovits J, Plow EF, Topol EJ. Platelet glycoprotein IIb/IIIa receptors in cardiovascular medicine. N Engl J Med 1995;332:1553-9. 